\title{
Hawaiian ways of Protection: acting for self- determined Indigenous futurities
}

Jean-Marc Serme

\section{OpenEdition}

1 Journals

Electronic version

URL: https://journals.openedition.org/ejas/17023

DOI: 10.4000/ejas. 17023

ISSN: 1991-9336

Publisher

European Association for American Studies

\section{Electronic reference}

Jean-Marc Serme, "Hawaiian ways of Protection: acting for self-determined Indigenous futurities", European journal of American studies [Online], 16-2 | 2021, Online since 13 July 2021, connection on 17 October 2022. URL: http://journals.openedition.org/ejas/17023 ; DOI: https://doi.org/10.4000/ejas. 17023

This text was automatically generated on 17 October 2022

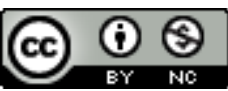

Creative Commons - Attribution-NonCommercial 4.0 International - CC BY-NC 4.0 https://creativecommons.org/licenses/by-nc/4.0/ 


\title{
Hawaiian ways of Protection: acting for self-determined Indigenous futurities
}

\author{
Jean-Marc Serme
}

\section{Introduction}

\section{Goals of the article}

1 Protection is identified in this paper as many different practices and positionalities which aim to prevent further harm to Kanaka storied places and people. It also means to mend and heal what has been damaged, in new and creative ways. Protection is one expression of the notion of kuleana which is connected to the central Kanaka concept of aloha 'aina, the love of the land. We must understand how the relationship to the land connects Kanaka Protectors if we are to interpret their actions in an Indigenous perspective. Genealogical connections between gods, elements, humans and nonhumans are the main framework that allows us to understand not only the actions, but the vocabulary used by Protectors to articulate their spiritual and political positions. Protection is meaningful thanks to the genealogical sphere of responsibility (kuleana) which everyone is meant to engage as part of the reciprocal relationship with kūpuna, human and non-human elders and ancestors. ${ }^{1}$

2 The main actualization of Hawaiian Protection recently has been the movement against the building of the Thirty Meter Telescope, an 18-story giant promoted by a consortium of US and international scientific institutions, on top of Hawai' i's sacred mountain, the volcano Maunakea (Hawai'i's Big Island). Standing at 4,207.3 m, the volcano's top is the gem location of the international astronomical community for the purity of its surroundings. To Kanaka people, it stands as the big brother, the first born of founding original god parents. Maunakea provides water and spiritual connections which engage Humans to protect the mountain in return, as a living family member. Nationalists 
have been asking for inclusion into the decision making process concerning the construction of telescopes on the mountain ever since the beginning of scientific programs began in the 1960s.

3 Many articles have been written about the recent events on Maunakea. I selected a few here to account for the diversity of viewpoints and common concerns about sacred Kanaka beliefs, the centrality of Maunakea in Kanaka spirituality, historical colonial dispossession, and contemporary political demands. They also express interrogations about how far colonial practices are capable of ignoring Indigenous beliefs and rights. This short list can be introduced by political scientist Leon No'eau Peralto's historically and genealogically poetic, visual, and analytical portrait of Maunakea. In 2018, a Kanaka scientists-led summary of demands centers on the need of soliciting Indigenous consent prior to industrial or scientific projects affecting their lands. Anthropologist Julia Hi'Ilei Hobart elaborates on her interest in the impact of Indigenous animacy against what she calls the "Western spatial imaginaries" that aim to suppress Indigenous presence in areas they hold sacred. Political scientist J. Kehaulani Kauanui rather sees in the controversy "negotiations of sacrality and legal strategy" while religion expert Marie Alohalani Brown insists on the sacred character of the mountain, but she also includes the long political struggle to defend the historical and cosmological framework of "Ho' omana (the set of beliefs and belief-related practices indigenous to Hawai'i)." Pacific Studies specialist Emalani Case shows how a "code of reverence" works between divine and Kanaka places, furthering their deep connection, but she also insists on the lack of access to land on Hawaiian shores to the point where she wonders with Protector Walter Ritte what will be left in the end. Political scientist Noelani Goodyear-Ka`opua refers to "protecting the possibilities of multiple futures," and "how to transform settler colonial relations with land." I have tried here to pursue in this direction and connect different acts of resistance in the recent Hawai i past. My contribution will present the notion of Protection in thick layers of meaning, encompassing both a sense of genealogical connection with land and people, but also a way to create "[c]ollective spaces where Indigenous peoples live their own visions of self-determination and freedom." In this view, Protection takes into account the past and the future, making informed decisions connected to Indigenous ways of knowing and the Kanaka worldview. ${ }^{2}$

\section{Defining "Protection"}

Knowledge is a bulwark against attempts at erasing the Kanaka past and its legitimacy. Abuse against Kanaka has never been passively accepted. Protection movements have faced and documented many forms of coloniality over the years such as imposition of private property (1848) and expropriation from agricultural land; mass immigration that overwhelmed a dwindling Native population (starting in the 1850s); EuroAmerican, illegal, takeover of political power (1893; 1898); and social relegation through the marginalization of Hawaiian language and culture as outdated and inadequate to the contemporary world (since the $19^{\text {th }}$ century). Annexation plans in the late 1890 s by the political junto ruling in Honolulu and its allies in the US were denounced by the Kū'è movement, vigourous petition drives by Queen Lili uokalani and nearly the entire Kanaka population; more recently, a place in the Constitution (1978), a language revitalization organization (1983), and several plans for a self-governing body (1990s-2000s) have been fought for, often successfully. Kanaka activism will here 
be seen as forms of Protection against processes of dispossession, assimilation and marginalization, the colonial practices accused of what historian Jon Osorio has called "dismembering lāhui," separating Kanaka people from their leaders and destroying the unity of the Kanaka nation. ${ }^{3}$

Protection is an expansive concept. From the narrow meaning of "to cover or shield from exposure, injury, damage, or destruction" to "perpetuate the life of our lands and peoples" or "renew connections" and honor the kuleana, responsibility, involved in the relationships between humans and non-humans, both Standing Rock and Maunakea Protectors agreed and recognized with Lakota Chas Jewett that "one must work not against what one hates (this poisons) but from what one loves (this heals)." The interest in finding new ways and solutions, which seems to be the ontological positioning of a growing number of Protectors all over the world, fuels the choices of examples and references made in this paper. ${ }^{4}$

6 The three parts that follow will demonstrate the double character of Protection as defense and as alternative possibility. In the first part, "ancestral relationships" are seen as the foundation of what it means to be a Protector, going back to cosmological beginnings and a worldview based on a genealogical order which binds the different elements of creation, and how they are related to one another. The second part shows how those relationships demand "continual maintenance" of reciprocal duties and create deep implications of concern and interconnectedness between humans and land, and all non-human creatures. Finally, Indigenous ways of knowing and worldviews make the resurgence of Indigenous governance possible and open multiple futures for a return to inclusiveness and interdependence of all species, within Kanaka society and beyond it.

\section{Positionality}

7 I am a researcher from France and an ally to the decolonization process as defined by Kanaka scholars Hokulani K. Aikau, Vernadette Vicuña Gonzalez, and Noelani Goodyear-Kā’opua as well as resurgence advocates and scholars Leanne Betasamosake Simpson (Mississauga Nishnaabeg) and Taiaiake Alfred (Mohawk) who sees in it "the Indigenous vision of what it is to be in struggle." Although writing here in English, I aim to focus on working in French in a country that is still struggling with its own colonial past and present. My goal is to make Native history and culture within the US sphere of influence, as it is written by Indigenous scholars, more familiar to French readers, and here to a European audience, and hopefully, inspirational for a change of attitude about France's and other European countries' settler and colonial policies mostly in Pacific and Caribbean occupied areas. ${ }^{5}$

\section{Methodology}

8 My paper will focus a lot on vocabulary and the multiple meanings of words in the translated context of Kanaka concepts from an outsider point of view. The warning put forth by Northern Arapaho writer Misty Perkins shall be heeded here: "For words are not just names and definitions, but hold entire concepts behind them and depending on the translation of words between languages, the message can often be altered or misconstrued." This article will thus focus on text and discourse analysis closely related 
to Kanaka history and cultural concepts. As critical dance studies scholar Shea Murphy advises, "radical performance practices" which can be both cultural practices but also what is usually interpreted as "protest" by mainstream media and government officials, should be construed less as challenges to the nation state and more as expressive of the identities and values of the "communities and political constituencies they constitute." 6

Thession not only of identity, but of the positionality of Protectors within Kanaka episteme, requires an understanding of Kanaka worldview references and history, calling for a topic-centric approach to oral and written testimonies of contemporary participants in land Protection, social improvement of Kanaka well-being, and nationbuilding efforts. Discourse analysis is inspired by a hermeneutic mode which uses interpretive techniques of discourse analysis in order to show how the events discussed here draw a thread between contemporary Protection movements and historical archives like the creation chant Kumulipo, but also the historical writings of $19^{\text {th }}$ century Native historian Davida Malo and Samuel Kamakau, or $20^{\text {th }}$ century cultural expert Mary Kawena Puku $i$ and Rubellite Kawena Johnson, down to the expanding $21^{\text {st }}$ century scholarship of a growing number of Kanaka researchers and practitioners on the work of whom I much depend here. ${ }^{7}$

Kanaka language and concepts play a strong role in the English-medium expression of Kanaka worldviews, made of rich metaphors, historical references to the monarchical period or pre-invasion times, Native epistemologies, famous ancestors or living senior leaders, the Kūpuna, and specific, often sacred place names. As such, language use shapes the speeches and interviews selected for this article: the choices I made were mostly framed according to the centrality of the explicitly stated Indigenous epistemology they contained.

This research is mostly based on existing oral interviews and written testimonies of participants. Interpretive methodology is favored here, focusing on culture specific and place-specific references to Hawaiian recent history and on mostly textual and audiovisual research. The time and space continuum created by Protectors in the historical and cultural references which form the intellectual background to their efforts amounts to what Abenaki historian Lisa Brooks has called a "common pot" which brings together "land, community, and the shared space of sustenance among relations." The article is also trying to detail a sense of shared endeavor by grassroots movements, embodying a type of community capacity building model in order to convince and compel the state of Hawai $i$ to endorse Kanaka self-determination goals. ${ }^{8}$

\section{The Kumulipo Chant and the "everlasting continuum" of life in Protection practices}

Protection movements need to be connected to the larger cultural references which shape the Kanaka mindset about the universe. Since the genealogical focus is so strong in Kanaka culture, the mele ko'ihonua, the creation chant, is central to linking subsequent generations to the beginnings of the world and the birth order of everything since. I will look at the Kumulipo ("Beginning-in-deep-darkness") because of its account of the genealogy of the last reigning dynasty of the Kingdom, connecting King Kalākaua and Queen Lili uokalani to the primeval events of creation as well as a long line of rulers before them. The chant will help us to understand the many 
references the Maunakea Kia'i, or Protectors, have used in recent years to define their political and cultural stand, in particular the feeling of responsibility to the mauna. ${ }^{9}$

\section{Celebrating Kaiimamao}

13 The Kumulipo is foremost a genealogical account of the connection between the ali $\mathrm{i}$, the ruler for whom it was composed, the origins gods he descends from, and the evolutionary appearance of life on earth. The chant is 2,102 verses long and it provides a full account of cosmological beginnings, from darkness (chants 1 to 7 ) to light (chants 8 to 16), from the time of gods and the creation of all creatures ( 1 to 7 ) to that of woman and man (chant 8), down to the generations leading to the child king it was intended for. Ka' Iimamao was the name given by his parents, but Queen Lili 'uokalani explains in her introduction that the bards who composed the chant named him Kalaninui'iamamao in order to elevate him in posterity ${ }^{10}$. The parents had still a more important goal in naming him: "when Keawe married Lonoma-I-Kanaka it was an infusion of a new royal blood with that of their own royal line of I, the father of Ahu, the grandfather of Lonomaikanaka." The importance of royal rank was primeval in the power system of the islands. Anthropologist Martha Beckwith indicates that "rank upon blood descent-hence the importance of genealogy as proof of high ancestry." In order to keep their power over other ali' $i$, top rulers had to choose mates who were equal in rank, which explains why brothers and sisters may mate with each other to keep their niaupi'o, divine, rank and create the "godly child." However, incest concerned only ali i, not maka'ainana, commoners. Cultural expert Mary Kawena Puku 'i provides several 'olelo no`eau, proverbs and sayings, denouncing such practices within commoners' families. Incest was considered "above the law" and uniquely used by the highest ranking families in order to protect their divine ascendance. ${ }^{11}$

\section{Creation of the universe: the Kumulipo as knowledge repository}

The origins chant focuses first on the creation of the world, before it details the genealogy of the young king's family. Kumulipo is the male element and Po'ele is the female element and "in their joining, everything else came forth", explains contemporary chanter Maile Naehu. She says that the Kumulipo details the development of the world in its order of creation. Cultural expert Rubellite Kawena Johnson likens the Kumulipo's description of life evolution to what Charles Darwin shows in the Origins of Species, going from the coral up to the most complex organisms on the planet. Cultural expert and kumu hula, teacher of hula, Pualani Kanahele, describes this process as the "organic inception of all family systems." Connections between ground and water initiate the great interrelatedness of the world: "[f]or nearly everything that is born in the ocean, a partner is born on land. The land partner is said to kia'i, or protect its senior ocean counterpart." The pairing of land and ocean's creatures forms "a strong relationship and responsibility between land and ocean and the creatures that live in both," which leads Johnson to affirm that humans have "no excuses for ignorance" and need to respect the antecedence of the land and water in their uses of them. The duty of Protection is inscribed into the creation chant because of the genealogical relationship and to forget it threatens the balance of the world, the legitimacy of hierarchy. ${ }^{12}$ 

along with the primary gods Kane and Kanaloa. She is the ancestor of Kanaka people in this chant. Papahanaumoku translates as "Papa who births islands." According to Kamehameha historian Pakui, translated by the reverend Abraham Fornander in the $19^{\text {th }}$ century, the Wākea tradition, through "the Song of Pakui," explains that "these islands were born from" Papa and Wākea's union. The chant goes:

Tahiti of the rising and Tahiti of the setting sun was born,

Was born the foundation stones,

Was born the heavenly stones,

Was born Hawaii;

19 The island of Hawai' $i$ (now referred to as Big Island) was the first born of the islands, and it is on that island that Maunakea was born. The volcano was the first born to the god Wākea, as told in a kānaenae, a chant of praise, written by a very famous $18^{\text {th }}$ century kahuna, a priest, Ka`opulupulu, which Peralto translates as:

Born is the Mauna, a sacred first born of Wākea.

So it is the Mauna, born is the Mauna.

The Mountain shall be below here. Who shall be above?

Who? The Sun, there! That is who.

Only the sun is above Maunakea, the most respected and hallowed mountain across the Pacific. It is the piko, the center, of the Hawaiian archipelago because it is so old. ${ }^{15}$

21 Another major account is the Song of Eternity, related in four articles published in the Honolulu Advertiser in 1956 by Samuel Apolo Kapi ikauainamoku. The koi honua, the genealogical chant, is the "endless story" of the Keawe family (Big Island), written for the Mo 'i, top ruler, Keawe-I-Kekahialiiakamoku, great grandson of the famed Umi-A-Liloa and father to Kalaninui-I-Mamao and the dynasty of Kalaniopu 'u for whom the Kumulipo was composed. The chant was performed in many ceremonies, 
Kapi' ikauainamoku writes, but the last full performance was at King Lunalilo's funerals in 1874. "Lengthy portions of it" were chanted at the coronation of King Kalakaua, successor to Lunalilo, and for the funeral of Queen Lili uokalani. In the second article, "Land of Wākea," the author tells of Wākea's sexual relationship with his daughter, Ho'ohōkūkalani, the starring of the heaven. Ho'ohōkūkalani gave birth first to Hāloanakalaukapalili, the long breath in the quivering leaf, who was still born. Wrapped in kapa and planted, it gave the first kalo plant (taro), the Hawaiian food staple. She has a second child from Wākea, a man, also called Hāloa, the long breath, who "survives and becomes the direct ancestor for all Hawaiian people." The kalo plant and man are then brothers and being the younger one, as in his relation to Wākea, man has to take care of the kalo as his older sibling, since the latter provides him with nourishment. ${ }^{16}$

This story not only builds on family relations, but it also creates a social structure for Hawaiian society which establishes interrelatedness and a hierarchy between all creatures and elements of the archipelago. Anthropologist Kekuewa Kikiloy writes that Papa and Wākea's union is "the 'birthing' of a unified Hawaiian consciousness-a common ancestral lineage." It appears then that the islands, the volcano, kalo and man are all closely related to the founding of the world, creating both a cosmological and political unity which must be protected by continuous loyalty to the land and those who reside on it across the ages. ${ }^{17}$

\section{The Sacred}

Poet and scholar Brandy Mc Dougall insists on how the Kumulipo shows that Indigenous genealogy, mo'okuhau'au, is central to Kanaka identity and authenticity, against the US colonial practice of measuring blood degrees, known as blood quantum. This is the recurrent question of definition. Who is a Kanaka? Anyone who can account for a genealogical connection to the Hawaiian past, no matter how tenuous, answer the Nationalists. Those with at least $50 \%$ Hawaiian blood, specifies US law. Many see blood quantum as a settler measure to erase Kanaka people in the end. Nationalists take the Kumulipo for "a sacred Hawaiian text" on the scale of the Bible or the Koran. McDougall also insists on its importance to the legitimacy of the overthrown Queen and the continuance of "Hawaiian sovereignty and governance" to this day, despite what they term as US occupation of Hawaiian soil. One of their most emblematic voices, lawyer activist Mililani Trask, says they never surrendered that tradition of Native governance and consider themselves to fall "under the United Nations category of a 'non-self-governing people." That's how the creation chant and contemporary politics meet on top of Maunakea, at the heart of the conflict between settler-state colonialism and the Indigenous claim to sovereignty derived from the monarch's divine origins. ${ }^{18}$

\section{Political Perspective}

The political perspective as regard the notion of Protection has been important in the colonial context of Hawai $i$, and in particular at the time of the overthrow of the Queen, the translator of the chant (1895-1897). King Kalākaua, the brother she succeeded in 1891, had a copy of the chant in Hawaiian, which he published in 1889, two years after he was forced to sign the so-called "bayonet constitution" at gunpoint, which despoiled him of most of his prerogatives in favor of the white-dominated Legislature and 
Cabinet. The Kumulipo was a way to remind Kanaka people that he was descended from a very powerful ali $i$ for whom a three-hour chant had been composed nearly two centuries earlier. It also expressed the connection between political and sacred realms, emphasizing the legitimate character of his successor and sister, the last Kanaka Queen. 19

The translation of the Kumulipo by Queen Lili uokalani between 1895 and 1897 started during the months of internment in her palace after the failed Kanaka counterattack of 1895 which she was accused of having condoned. She meant to show the American people the depth of Kanaka history and political independence, for the text tells the story of "eight hundred generations of Native governance," McDougall reminds us. In such a time of crisis as the Kanaka people and their ruler were going through at the end of the $19^{\text {th }}$ century, such a reminder of a millennia-old tradition dwarfed the events of Euro-American takeover, however tragic they were at the moment. It also confirmed the genealogical legitimacy of the Queen's family, "her descent from a succession of proud monarchs" as it was composed for Ka'İmamao, the ali i, the ruler whose daughter was Lili'uokalani's great-grandmother. The Kumulipo, which the Queen termed "the only record of its kind in existence," was worth protecting for its historical significance and long enumeration of Kanaka rulers. It offered protection against Kanaka erasure by the regime change of 1893 and the cultural eradication of the Indigenous population. Memory and legitimacy would thus be preserved for generations to come. ${ }^{20}$

Since the 1970s, two modern Protection movements have been strongly influenced by origins narratives and their connections to wahi pana, the sacred places. They took upon themselves to revive or preserve the reverence Kanaka people have had for them. From 1976 through 1990, the Protect Kaho'olawe 'Ohana (PKO) battled the US military and the state to put an end to the recurring bombing of the Kaho'olawe island and its general use as a live-fire training installation since it was requisitioned and closed to non-military people under martial law in 1941, without Kanaka consultation. A small uninhabited island south of Maui, it holds a special place in Hawaiian history since it is supposed to be the kinolau, the embodiment, of the sea, long-distance voyaging and healing god Kanaloa, one of the four major gods of the islands. Kaho'olawe is strongly connected to the first Polynesian navigators who arrived on the island from the South Pacific over a millennium ago. Protectors landed several times on its shores in 1976 and 1977 despite restrictions, and claimed their right to access this Hawaiian, not US military, sacred land. They were awed by the place. More than 3,000 archeological items led to its being put into the National Register of Historic Places in 1981. After about forty years of relentless bombing and goat ranching, the shrine was marred by soil erosion: "the devastation on the land was so "in your face," veteran PKO member Walter Ritte Jr. remembers in an emotional tone. Kaho'olawe, a landmark in Polynesian settlement, today envisioned as a future "cultural learning center," was seen in the early Hawaiian Renaissance as the embodiment of the horrors of the military occupation of Hawai' i. ${ }^{21}$

The main instance of Protection for this article is the ongoing movement defending another wahi pana, storied place, against the construction of a giant $14^{\text {th }}$ telescope on the volcano Maunakea, the piko, the center, of the Hawaiian world. Thousands of Kanaka Kia i, Guardians or Protectors, blocked the access road to the top in July 2019, following actions in 2014 and 2015 that aimed to interrupt the ground breaking 
ceremonies and the hauling of heavy equipment to the top of the mountain for the $\$ 1.4$ billion international project. Among repeated decades-long accusations and evidence of mismanagement of the mountain against the University of Hawai $i$ and the state, the controversy has led to occupation periods, arrests, countless articles and social media activity, and international attention at one point connected to the \#NoDAPL protection movement in North Dakota. ${ }^{22}$

The controversy over Maunakea has strong political overtones, because it has been the symbol of Kanaka jurisdiction over the islands since time immemorial. The intrusion of scientific equipment up there dates back to the 1960s. But more importantly, the controversy also questions who is consulted in key land management decisions and how the law manages this part of the Hawaiian lands domain. Protector Gene Tamashiro asks a central question about Maunakea and all Hawaiian lands: "Who has title?" For him, as a "true Kanaka, sovereign Hawaiian national" echoing many Aloha 'Āina or Nationalists' perspective, the legitimacy of the state of Hawai' $i$ to hold Maunakea in trust and of the University of Hawai i (UH) to lease that land, and the overseeing powers of the state Department of National Lands and Resources (DNLR) to manage the area, are void because of the unlawful overthrow of the monarchy in 1893, the unlawful US "annexation" of 1898 and the subsequent unlawful occupation of the Islands by the US until today. Tamashiro also sees the referendum of 1959 that led to statehood as unlawful. For Nationalists, illegality has been the rule of law since the overthrow of Queen Lili uokalani in 1893, defying official recognition of the kingdom by the US fifty years earlier. ${ }^{23}$

Eventually, many think Maunakea should be left alone, standing too high for human activity and understanding, as kumu hula and cultural expert Pualani Kanaka'ole Kanahele suggests: "Mauna Kea was always kupuna to us ... And there was no wanting to go to top. You know, just that they were there ... was just satisfying to us. And so it was kind of a hallowed place that you know it is there, and you don't need to go there. You don't need to bother it." The sacred character of the mountain made it difficult to access and a privilege to do so. Yet, stories and religious practices have kept Maunakea at the firmament of Kanaka spirituality. Despite the colonial takeover, the responsibility and care that ancient texts and Kanaka tradition have defined still hold and "continual maintenance" is still required in contemporary settings. ${ }^{24}$

\section{2. "Continual maintenance": Kanaka concepts and relationality define Protection}

This second part will be devoted to exploring what political scientist Leon No'eau Peralto (2014) has called the "continual maintenance" of the interconnectedness with the land. That concern requires dedicated involvement, responsibility and duties over time, all words which describe the concept of kuleana, or sphere of responsibility. We will see what the meanings of Protection are, how they rely on the understanding of the concepts of `āina and aloha 'àina. Such knowledge has had to be taught again in the last half century to a population waylaid by Western-oriented education which erased the teaching of Hawaiian culture until the Renaissance of the 1970s. Finally, the notion of 'ohana will be explored as the embodiment of the relationality embodying the intricate networks of reciprocal care between what aloha aaina Protectors, or Nationalists, call the lāhui, the Kanaka nation. ${ }^{25}$ 


\section{Protect, not protest} Standing Rock (North Dakota) and on Hawai i's highest, most sacred, mountain, Maunakea. Ojibwe Water Protector Winona LaDuke explains clearly that "it's important to claim the language and to not be trivialized or minimalized as to who we are". Thus, making the distinction between the two concepts places Indigenous movements within their own frame of references and provides agency. Writing for Indian Country Today (2016), Misty Perkins (Northern Arapaho) states that the concept of protest does not reflect the "reciprocal relationship" that Indigenous people maintain with the land. Perkins explains that difference in terms of world views where non-Indigenous people look at the land with greedy eyes, defending property, access, or free usage, while Indigenous people "relate to the earth as our relative and honor that connection by way of life and in ceremonies." It is no new age concept, but it is a religious and spiritual approach best understood through the genealogy I mentioned in the previous part, and the concepts related to the `aina, the land. ${ }^{26}$

\section{‘Āina}

The translation of 'Āina is often restricted to "land", but as with relations, it encompasses much more and connects the individual, their family and the universe and all the interactions in between. Anthropologists Mary Kawena Puku`i and E. S. Craighill Handy define it as "deriving ... from the verb 'ai, to feed, with the substantive suffix na added, so that it signified 'that which feeds' or 'feeder." They add that people considered their Native soil as their feeder, but also the "[1]and of birth was also referred to as kula iwi (plain of one's bones) or one hanau (sand or soil of birth)." The land is intricately linked to birth, sustenance and death, connecting physically and psychologically the living and the dead, members of the family, 'ohana, and the wider system of relationality. ${ }^{27}$

33 'Āina can also be seen as a more generic concept that encompasses the land, the ocean and everything on and in them, as the Kumulipo describes their near simultaneous creation:

The sea spread, the land spread,

The waters spread, the mountains spread,

(Kumulipo, Third Era)

Peralto mentions the 'ahupua a Ka`ohe which is one of the land divisions going up from the ocean to the top of Maunakea. Ka ohe refers to the bamboo, which Peralto tells us is a kinolau, a physical form, of the god Kāne, used to transport water during ceremonies. This reference shows that maintaining a just, rightful relationship with the mountain and its god ensured continued access to the precious water, hence the concern with the construction of the telescope whose waste waters and other leakage may endanger the drinking water of the island despite scientific affirmations of safety. Caring for both land and water dates back to the early days of creation as well as rests on wise present and future land management practices. This is a legacy, as Kanaka families have for a very long time occupied diverse parts of the division, sharing products from the land and the ocean, and making up the maka ainana, the people on the land. ${ }^{28}$ 
Kanaka culture is place-based and celebrated in countless stories, chants and prayers which protect and maintain relationships to an acceptable level. As teacher and Maunakea Protector Ku'uipo Frietas explains,

When we say ‘aina, we don't just mean land. It means all things in relation to the land that we live on and survive on. It is the love we have for our language, culture, resources, ali'i (rulers), chants, stories, legends, people and more. It is the encompassment of everything to do with our culture and history as a people of Hawai i.

Protecting life and its development involves including it into one unique concept that every member is bound to protect. That connection is aloha 'aina, the love of the land which generates and regenerates reciprocal relations that have guided Kanaka for centuries and that works like a theory of social organization and structure. ${ }^{29}$

\section{Aloha `Āina}

Author and spiritual guide Pilahi Paki revealed in 1970 some of the essential qualities of the concept of aloha to the people assembled at the Governor's Conference on the Year 2000 who were trying to grasp the many layers of its definitions:

A akahai meaning kindness (grace), to be expressed with tenderness;

L lōkahi meaning unity (unbroken), to be expressed with harmony;

O 'olu'olu meaning agreeable (gentle), to be expressed with pleasantness;

$\mathrm{H}$ ha'aha'a meaning humility (empty); to be expressed with modesty;

A ahonui, meaning patience (waiting for the moment), to be expressed with perseverance.

These qualities are not only abstract notions. They hold a practical and concrete quality that is very often required in Hawaiian thought. Cultural expert George Kanahele reminds us that aloha should be lived more than explained. He also points out that Aloha most likely refers to the original bond between parent and child. As an ancestral living entity, it is no wonder that 'aina should receive as much aloha as any close family member. In a 2016 Hawai i Public Radio program on how to understand the concept of aloha 'āina, poet Aunty Puanani Burgess suggested how these feelings of kindness, gentleness, and humility were characterizing the necessary attitude toward the land. She referred to the practice of honi, where "I put my nose next to your skin and I breathe you in." Having this kind of emotional response when interacting with the land brings a lot of contentment and self-reflexion, says assistant professor in Indigenous crops and cropping systems Noa Kekuewa Lincoln. Burgess refers to the power of dreams where visions of "forests of koa and 'iliahi" allow her to "breathe in the deep scent of that land," to "understand what she is teaching me." To love the land is first an exercise in humility and observation, of quiet acceptance and progressive understanding of what the land is communicating, of what there is to understand in the relationship. These are some fundamental aspects of Kanaka ways of knowing. ${ }^{30}$

The physical encounter with the land and self-exploration lead to consider "the way the world works through interacting with the land," adds Lincoln. It's a complete process which the relationship allows, "with different layers of meaning," explains Hawaiian Studies Professor and PKO member Davianna Pomaika'i McGregor in the same program. Notions of respect for the land, but also of deep pride, bring about the fact that "those who are aloha 'âina are people who are nationalists and have a strong sense of patriotism for Hawai' $i$ and the land of Hawai i," she continues. The Protect 
Mauna Kea movement is in this sense deeply political. Concerns for the environment are important, but the Kia' $i$, the Guardians, have been primarily outraged at the lack of consideration for Kanaka Protectors (the elders in particular) and the sacred notion of aloha ‘āina and mālama `āina. The intrusion of telescopes on Maunakea dates back to 1968 with little to no consultation of Kanaka experts ever duly taken into account. But aloha 'âina as a political tool dates back at least to the late $19^{\text {th }}$ century. ${ }^{31}$

Protect Kaho`olawe 'Ohana (PKO)'s co-founder Noa Emmett Aluli explains how the organization retrieved the phrase aloha ‘aina from his "great grand-aunt Emma Aima A'i and her husband Joseph Nāwahī, leaders of the Hui Aloha 'Āina (Hawaiian Patriotic League) and editors of the Ke Aloha Aina newspaper," referring to the structured opposition of Kanaka leaders to the 1893 overthrow of the monarchy and the US process of "annexation" that followed. Historian Jon Kamakawiwo'ole Osorio indicates that aloha 'äina "comes to be the message that is trying to bind Hawaiians together to oppose the loss of an independent government." From spiritual connection to political arguments, aloha 'āina has provided a frame for a wide-ranging set of Kanaka issues in favor of Indigenous ways of knowing and the process of indigenizing colonial history. It has led to a more central place of Kanaka agency in the narratives and to demands for more participation of Kanaka citizens to the decision making process concerning the management of Hawai' i's environment., This process of empowerment has been seen as a road to Native self-determination and sovereignty, but the Renaissance has demonstrated that in order to achieve such goals, a large effort of educating the population was necessary. ${ }^{32}$

\section{Education}

41 There was a sense of loss in the 1960s and 1970s, a sense that Hawaiians were losing their links with their past, their language, their history and their values, and the maintenance of culture was threatened. It was also a time when Native American groups were reviving a subdued and repressed history, with the Indians of All Tribes occupying Alcatraz where, "[w]ithin three weeks of the occupation, a school was set up," and the American Indian Movement at Mount Rushmore or Plymouth Rock. They meant to call for change by targeting important landmarks as educational tools for the public. Since the early Hawaiian Renaissance, activists have felt the need to bring back the information and knowledge that had been voluntarily suppressed by the colonial strategy of erasure. ${ }^{33}$

42 Kawaipuna Prejean, founder of the Hawaiian Coalition of Native Claims, which would later become the Native Hawaiian Legal Corporation, "an active non-profit law firm specializing in Hawaiian land rights," said in 1992 that "attempts at eliminate[ing] ignorance" were capital to raise awareness and understanding," and "sharing information that does not get distorted in the mainstream media" became an everyday battle for revitalization and self-determination. The lack or selective output of information about Hawaiian history in public and private schools was massive and remains problematic to this day. Americanization had been implemented since the late $19^{\text {th }}$ century as a means of erasing Hawaiian history and culture while imposing both English and a middle class view of society. By the early 1970s, it had been quite successful as the general population knew little about the overthrow of the monarchy 
and even less about the heyday of Kanaka royal governance. Every act of Protection has since been a locus of education for Protectors and the people of Hawai $i{ }^{34}$

This history of dispossession had to be told. And it still does. Sovereignty movement photographer Ed Greevy recalled Save Our Surf (SOS) John Kelly's definition of an activist and the role of education: "to help [people without power] to get information they don't have access to... and help them develop a plan and do it." Protectors today have built upon this definition by enriching it with cultural references and genealogical meaning. People involved in Protection movements have been avid learners. Reading everything they can, looking up to kūpuna, elders, for information about the old ways and their Hawaiian lifestyle, they have also closely studied the projects of developers they have opposed, checking the legality of the process. To John Kelly as to George Helm, and today to the new generation of activists like Freitas, education has been everything, a base that provides the means to uncover and change the official narrative of the harmonious Aloha state. ${ }^{35}$

Kanaka singer and PKO leader George Helm was obsessed with knowledge as tool, frantically studying Kanaka history. He expected people to do the same: "do your homework!" he would command. Nainoa Thompson, the Hōkūle’a master navigator who learned the old star navigation skills of wayfinding in the 1970s, is also focused on educating the next generation: "[Education] is the keystone to health - to the health of the individual and that of society." In 2014, he and educator Robert Witt founded the Mālama Honua Charter School, "rooted in our Indigenous cultural values," and meant to "help students develop into wise, compassionate navigators of their learning, their lives, and the 21st century global world." Education also means a change of heart and vision and to bring forth alternative values to individualism and consumerism. It is also a measure of relationality or a web of social interactions as compassion is one of the meanings of aloha and involves a deeper relation to the other. ${ }^{36}$

As Alcatraz or Mount Rushmore were locations of learning, Hawaiian special places have been central in the teaching/learning process. In 2016, Protector Ku'uipo Freitas said that Maunakea was an educational tool to "make the whole world understand ... that we've been illegally occupied since 1898." Kaho'olawe was the same as aloha 'äina, George Helm taught students in one of his talks. As a kinolau, an embodiment of the ocean god Kanaloa, the island was Hawaiian history being desecrated in front of people's eyes. Caring for the island also meant de-westernizing land management. For Helm as for many Indigenous people, the land should be "nurtured and respected," that was the first step of learning about it. The island had been so badly damaged by live fire that a huge restoration enterprise was decided in 1994, with the military hiring a private company to start the cleanup. In the early 2000, "Reviving Kanaloa" took over and was about restoring the entire island, and it has had to be learned and taught. Defense and restoration became one in the Protection of the sacred island. Twenty-five years later and despite huge continued efforts, only a tiny part of the island is back to nurturing life. In 2014, Kanaka were consulted in a spirit of community outreach, and four goals were devised to structure the rehabilitation of the island: "Renew connections; live sustainably; elevate knowledge, realize identity." Once again, education was part of the plan. ${ }^{37}$

Community-run information output like teach-ins have been classic initiatives since the civil rights movement, and it was widely used by the Indigenous Canadian movement, Idle No More, just a few years back. During the occupation of the Maunakea 
access road, Presley Ke'alaanuhea Ah Mook Sang, a Hawaiian language instructor at the University of Hawaii at Mānoa, suggested a community-led school to teach Protectors and allies about Maunakea and Indigenous thought. That's how "The Pu'uhonua [the refuge] has become a place of convergence for the lāhui Hawai' $\mathrm{i}$ and the [Pu'uhuluhulu] University facilitates sharing and exchanging this vast knowledge with each other, teaching mele and oli, malāma 'āina practices, literature, history and mo'olelo, sciences, art and more." Ilima Long, another initiator of the project, said that Maunakea was also "the result of education," the capacity to know about history and to teach the complexity of Kanaka thought and knowledge gained through decades of research and teaching by Kanaka scholars. ${ }^{38}$

Protectors have always encouraged people to learn. Ku' uipo Freitas repeated Helm's credo when she declared, "If you're unaware, take the initiative to educate yourself." Cultural expert George Kanahele reminded his readers of this old Hawaiian value that "only knowledge of your roots can validate and glorify what you are and can become," which amounts to saying that one must look to the past to know their future. Recreating a learning environment where Kanaka knowledge and culture made sense to the present is also a road to rebuilding a sense of community, even of lāhui, or nation. ${ }^{39}$

\section{Resurgence}

We are frequently reminded that acts of Protection are "acts of sovereignty, cultural survival, and decolonial struggle" (Fiskio 127). The heritage of Aloha “äina keeps inspiring what political scientist Mary L. Baker calls "resurgent practices of Indigenous peoples" (ii) and cultural practitioner Sam Ka'ai, "taking hold of the old story once again." Leon Peralto calls "piko of resurgence-people, places, and practices that converge in regenerative spaces, referred to ... as kīpuka aloha 'äina." Developing these points of view, this part will look at how Protectors involved in cultural and political resurgence create Indigenous settings where Native epistemologies and ways of knowing find meaning and significance primarily within Indigenous communities, without reference to settler colonial structures. This strategy is seen as preferable to constant claims to state authorities and the subservience they implicitly recognize to the established system. ${ }^{40}$

\section{The dynamics of Kanaka zones of resurgence}

These "acts of resurgence" aim to map "traditional knowledge and values" in order to contribute to "a radical futurity" challenging the cultural and political premises of the dominant system. Law professor and 'āina-based educator Kamanamaikalani Beamer looks at the highly successful system upon which his ancestors flourished and sees archival records of traditional land divisions as "living models" to be looked forward to. Aloha 'äina is a "union of culture and ecosystem," he writes. It's the dynamic relationship between the land and people which makes it "āina." He does not propose a naïve version of the concept. He reminds us that aloha is "active and something that needs to be put into practice," particularly in front of the serious social, economic, and political evils which stand in the way in Hawai ${ }^{4}{ }^{41}$ Aloha is both ideal and practical, requiring the capacity of vision as well as of pragmatic feasibility. 
Kanaka concepts are not static, they involve dynamic and constant actualization of the ideas they convey. George Helm explained that his concept of "revolution of consciousness comes from the word revolving, turning in and out so that you have something better, better to live with." The revolution of consciousness involved a major change in the way people lived on the islands and how poverty, social relegation, lack of healthcare or education affecting Kanaka could be fought and defeated by a return to Kanaka values. In order to explain their worldview about the Mauna, Protector checkpoints on the Maunakea road "created a space for dialogue and an opportunity to engage in discussion." They talked to police officers, tourists, local people, families, focusing on interaction and understanding instead of opposition and violence, articulating what a pono, just, right, balanced, future, could be. The concept of futurities expresses the multiple alternative views and possibilities contained in Indigenous ways of knowing and acting. On the contrary, "settler futurity" seems bent on a unique path of "progress and development" subservient to mass consumption, carbon-based energy, corporate practices and Western-oriented worldviews. The goals of bringing out new ways of relating to one another and recreating a Kanaka framework implied new structures and more references to what 19th century ali i, rulers, had devised, between a western-inspired state and the open minded and integrative Kanaka Lāhui, nation, devised by Kanaka monarchs. ${ }^{42}$

51 For now, quoting feminist activist Andrea Smith, Noelani Goodyear-Ka'ōpua advocates "autonomous zones" which she translates as pu uhonua, "places of refuge" which, in traditional Hawai $i$, used to protect from harm those who sought shelter there. She says the point is to create Indigenous enclaves against the assaults of colonial institutions based on Indigenous ways and behavior. Cultural practitioner and Protect Mauna Kea movement alaka $i$, leader, Pua Case, details the Kanaka structures put in place between 2015 and 2019: "[o]ur traditional practice includes Cities of Refuge, a Kapu system and village system... our traditional governance and organization." The kapu system is a strict discipline that mixes religious devotion and respectful behavior. These different cultural references led the Protectors to look at their own frame of reference and organize organically as Indigenous people acting Indigenously. ${ }^{43}$

Nez Perce and Tejana professor Inés Hernández-Ávila speaks of "zones of refuge" which Mohawk Taiaiake Alfred and Cherokee Jeff Corntassel call "a powerful conceptualization of a strategic and cultural objective that remains consistent with traditional goals yet stands against the integrative goals of the contemporary colonial agenda." For Goodyear-Ka'ōpua, they are the horizontal, compassionate and inclusive loci necessary for empowering "practitioners" who are the closest to 'āina and have "the most intimate and in-depth knowledge of particular resources," such as lo'i kalo, taro patches. Finding an Indigenous path is a way to denounce the "politics of demand," Goodyear-Ka'opua argues. Using sociologist Richard F. R. Day's phrase, she denounces an attitude which keeps activists in a subservient position to the colonial state. In other terms, organizations must find places where people can experience the lāhui, their nation or nationhood, in a Kanaka mindset, and where political affirmation is made free of the constant reference to or expectations from settler state institutional structures. ${ }^{44}$ 


\section{Kanaka self-governance and international connections}

53 the centennial anniversary to the overthrow of the monarchy (1993). As activist and scholar Haunani-Kay Trask so clearly stated: "[T]he Hawaiian Movement began as a battle for land rights but would evolve, by 1980, into a larger struggle for Native Hawaiian autonomy." In the 1990s, Ka Lāhui Hawai i became the most influential Native organization asking for a status for Kanaka, which they still lack as a cultural entity today. The hui, led by Kanaka lawyer Mililani Trask, after setting up a giant demonstration for the centennial of the Queen's overthrow in 1993, came up two years later with Ho'okupu a ka Lāhui Hawai i, translated as a "Master Plan for Hawaiian SelfGovernment." The plan went into great details to define what the organization viewed as "the establishment of an Indigenous sovereign nation" under international law and focusing on the restitution of national lands confiscated by the US at the time of "annexation" (a term rejected by Nationalists). ${ }^{45}$

Another initiative that worked as a Protection movement and a self-determination project outside of state institutions is the Pu'uhonua o Waimanalo, a village and place of refuge which was established in 1994 by the Nation of Hawai $i$, under his leader Dennis Bumpy Kanahele, "to regain control of their lands and their lives" on 45 acres of land on O'ahu island after Kanahele organized an occupation of Makapu'u Beach Park in 1993 and negotiated the land deal with the state. Since no lease for the land has ever been signed, the Nation of Hawai $i$ claims the village to be the site of "a unique land 'occupation' in Hawai 'i." The village is today working at building "a community-led internet access" within the same vision as in 1994: "to achieve self-determination and self-sufficiency, with a harmonious balance of traditional Hawaiian practices and innovative modern technologies," said the deputy Head of State Brandon Makaawaawa in 2019. In short, those movements have worked at building modern Native agency within a Kanaka framework, a highly resurgent endeavor which is part of an ongoing political construction of Indigenous futures (including settler people) for the islands. The claim that Indigenous people from Hawai'i were not Americans, but HawaiiansTrask even shouted that "We will die as Hawaiians" in a famous speech in 1993-took on a meaning that is asking broadly how Native Hawaiians can have more of a role in decision making in the way the presents and the futures of the islands are decided. ${ }^{46}$

In the words of Professor of English Candace Fujikane: "Indigenous ancestral knowledges are now providing a foundation for our work against climate change, one based on what I refer as Indigenous economies of abundance - as opposed to capitalist economies of scarcity." Economics of abundance have received a large interest in the $20^{\text {th }}$ century, when some economist and social theorists such as Murray Bookchin and Buckminster Fuller (1970s) and recently William Hoeschele, denounced the scarcity artificially created by capitalism to favor the few at the expense of the many, instead of generating general access to wealth and social justice. Indigenous theorists have also provided alternative views like the notion of a gift economy for which "Gratitude and reciprocity are the currency." In this view, a "return" to Indigenous ways would not be a step to the past. It would rather be a shift back to fundamental values which a growing amount of Western thinkers seems to be now considering in the light of mounting worries about climate change. Community movements across the planet are now attempting to set up alternative systems, involving local economies, recycling, 
collective land management and urban planning. Kanaka solutions based on cooperation and sustainability may well become inspirational in the years to come. They must however be connected to better integration in decision making at the local and state levels. ${ }^{47}$

FPIC (Free Prior Informed Consent) has become a necessary evolution in the path to a more autonomous Indigenous polity. Established as a right in the UN Declaration on the Rights of Indigenous Peoples (2007), it is still a hotly debated political measure of Indigenous agency, or lack thereof. The imposed construction of the Thirty Meter Telescope (TMT) on Maunakea is a case in point. The controversy over Mauna Kea started in the late sixties and Hawaiians were never given a real seat at the table. This is an issue of historical injustice, or rather, as political scientist Jeff Spinner-Halev has called it, a matter of "enduring injustice." Winona LaDuke thinks that the issue of FPIC is now "about who gets to decide the future and understand and interpret the world," placing an ontological challenge on the movement. What identity can Hawaiians claim if they cannot make decisions about what is sacred to them? ${ }^{48}$

The Polynesian Voyaging Society, the organization which built Hōkūle`a and has resumed wayfinding navigation in the Pacific, has turned to international advocacy, using Hawaiian concepts to address the world's (and Hawai' i's) problems. In 2013, the double-hulled canoe Hōkūle’a started a round the world trip, called The Mālama Honua Worldwide Voyage 2013-2019, which aimed to carry aloha ‘aina to the next level, i.e. a global one. By looking at Earth as an island, Pwo (Master) navigator Nainoa Thompson and a team of experienced and learning navigators, along with hundreds of volunteers around the world, launched into an attempt to address the planet's problems from a Hawaiian perspective. Warning against waste and overutilization of natural resources, Thompson spoke from an Islander perspective when he said: "Living on an island chain teaches us that our natural world is a gift with limits and that we must carefully steward this gift if we are to survive together." Mālama suggests the conscious knowledge of the finite dimension of the world as an island. As Hawaiians were able to thrive in the archipelago for over a thousand years, they seem to be uniquely positioned to send a wakeup call to the rest of island Earth, and provide solutions tapping into centuries of self-sufficiency with limited resources. Protest remains reactive and somewhat conservative. Protection has a sense of purpose and a future. ${ }^{49}$

\section{Conclusion}

Noelani Goodyear-Ka'ōpua reminds us that '“Protection' of native foods and a people's capacity to grow and relate to those foods on their own terms demands not only metaphors of confrontation and violent self-defense, but also of nurturing and procreation." This paper has focused on these aspects of nurturing and care as well as on Kanaka perspectives for the future. ${ }^{50}$

59 As Candice Fujikane writes: "a restorative change catalyzes far-reaching and often unexpected forms of revitalization." Such revitalizing occurrences have been spurred by long-term involvements such as the restoration of Kaho'olawe, the language revitalization effort, the sovereignty movements and the struggle against biocolonialism, and the Protection of Maunakea. These terms all refer to defense, conservation, renewal and creation. Ikaika Ramones reminds us that "land serves a dual purpose": "as a means of concrete social reproduction" which helps Kanaka 
families survive the onslaught against their culture and family bonds; and "as critical ontological bases for Hawaiian lifeways and worldviews" which are being defended today by the Protectors of Maunakea. Following the trend set by Goodyear-Ka`ōpua, I have tried to focus on a cultural-political approach to initiatives that created spaces for Kanaka people to implement the lāhui within a Kanaka framework. However, court challenges and direct action tactics are also used and often necessary to defend Kanaka interests. ${ }^{51}$

Franz Fanon explained that "the native is a being hemmed in." There is no space where colonized people can go freely, and it is particularly true in Hawai i where the shoreline has been privatized and made inaccessible in many places to Kanaka. Fanon writes that colonized people have learnt "not to go beyond certain limits." That is what Protection has meant both to challenge and to rewrite in its own words, concepts, and spaces. That's what resurgence is about. Betasamosake Simpson (Mississauga Nishnaabeg) takes Cherokee scholar Jeff Corntassel's advice to "center our individual and communal lives around renewal," and experience daily Indigenous innovative lives. ${ }^{52}$

61 Heirs to the Hawaiian Renaissance abound today. As the daughter of activists Soli Niheu and Gwen Kim who met on George Santos's roof in 1971, physician Kalamaoka'aina Niheu has been handed down much of what her parents have fought for over the years: "Born on the front lines of the Hawai i independence," movement, she continues community advocacy as "co-founder of the Mauna Medic Healers Hui" and "medical officer for Hokule'a," among other kuleana. Another heir is Andre Perez, an activist and community organizer from Kōloa, Kaua'i, co-founder of the Hawai' $i$ Unity \& Liberation Institute whose "mission is to provide nonviolent direct action training and action support in Hawaiian communities." He was presented as "the one that has taken the baton from the previous generation and brought that practice into now." ${ }^{53}$ The passing of Kanaka culture from one generation to the next seems to have rebounded at last.

Many young Hawaiians today feel a sense of empowerment. Movements attempt both to revive a cultural sense of collective identification with Native values, to the point that a life change is expected, while working politically for recognition and rights which may lead to self-determination and more sovereign self-government. The Lāhui ka Hawai'i's Master Plan and Moloka'i's active Protection of its land against biochemical are two examples of Kanaka knowledge applied to contemporary situations with the next generations in mind. Today, Maunakea is the latest of the never-ending battle between industrial and corporate interests and community concerns about their physical and spiritual integrity. As Ramones writes about the Protection of Maunakea, "we must appreciate that this is by no means an 'event,' but instead is ongoing processes of accumulation and class relations reified and valorized as a site of action." As such, Maunakea is not an attack on science, but the latest occurrence of Kanaka resistance to the encroachment of non-Indigenous powers which refuse to acknowledge the Kanaka voice in the contemporary world. ${ }^{54}$

Evidently, the landmarks of the Hawaiian Renaissance have helped morph a cultural revival into a larger political framework which has turned the language into a flagship, the overthrow of Hawaiian rulers and the dispossession of common Hawaiians into founding issues for rebellion and civil disobedience until the rights of Kanaka are not only fully restored in the legal system of the 50th state, but will take that entity into a 
new worldview where the legitimacy of the Natives of Hawai $i$ will be restored to the level of their sovereign ambitions.

\section{BIBLIOGRAPHY}

Aikau, Hokulani K., and Vernadette Vicuña Gonzalez (ed.). Detours: A Decolonial Guide to Hawai 'i. Raleigh: Duke University Press, 2019

Aikau HK., N. Goodyear-Ka'ōpua, and NK Silva. "The Practice of Kuleana: Reflections on Critical Indigenous Studies Through Trans-Indigenous Exchange." in Aileen Moreton-Robinson, Critical Indigenous Studies. Engagements in First World Locations. Phoenix: University of Arizona Press, 2016: 157-175.

Alfred, Taiaiake, and Jeff Corntassel. "Being Indigenous: Resurgences against Contemporary Colonialism." Government and Opposition 40, 4 (2005): 597-614.

Alfred, Taiaiake. 1968-2018 Conference: "From Red Power to Reconciliation," Institute for the Humanities, Simon Freiser University (Nov 30, 2018). Accessed May 31, 2021. https:// www.youtube.com/watch?v=jV_ohK28PiI.

"Aloha Rising: The History of Activism and Non-Violent Direct Action in Hawai' i (Episode 8)." OHA Hawai i. Video, 1:41:09. Accessed Jan. 16, 2021. https://www.youtube.com/watch? $\mathrm{v}=\mathrm{aB} 5 \mathrm{xi}-63 \mathrm{r} 8 \mathrm{E} \& \mathrm{ab} \_\mathrm{channel}=\mathrm{OHAHawaii}$.

Baker, Mary L. Ho 'oulu 'Āina: Embodied Aloha 'Āina Enacting Indigenous Futurities. PhD Dissertation in Political Science. University of Hawai i. 2018. Accessed on May 8, 2021. https:// scholarspace.manoa.hawaii.edu/handle/10125/62695.

Beamer Kamanamaikalani. No Mākou Ka Mana-Liberating the Nation. Honolulu: Kamehameha Publishing, 2014.

Beamer, Kamanamaikalani. “Tūtū's Aloha `Aina Grace.” (11-17). In Yamashiro, Aiko, and Noelani Goodyear-Ka'ōpua (Eds.) The Value of Hawaii 2: Ancestral Roots, Oceanic Visions. Honolulu: The University of Hawai i Press, 2015.

Beamer, Kamanamaikalani, Axel Tuma, Andrea Thorenz, Sandra Boldoczk, Keli'iahonui Kotubetey, Kanekoa Kukea-Shultz, and Kawena Elkington. "Reflections on Sustainability Concepts: Aloha 'Āina and the Circular Economy." Sustainability 13(5), 2984 (2021). Accessed June 4, 2021. https://doi.org/10.3390/su13052984.

Beckwith, Martha. The Kumulipo: A Hawaiian Creation Chant. Honolulu: University of Hawai i Press, 1951.

Blackford, Mansel G. Pathways to the Present: U.S. Development and Its Consequences in the Pacific. Honolulu: University of Hawai'i Press, 2007.

Brown, Marie Alohalani. "Mauna Kea: Ho'omana Hawai'i and Protecting the Sacred." EquinoxOnline (2016). Accessed May 31, 2021. https://doi:10.1558/jsrnc.v10i2.27795. 
Burgess, Puanani. "Puanani Burgess reads from The Mouse is Dreaming." Get Caught Reading. PBS Hawai $i$. Video, 1:05. Sept. 3, 2020. Accessed Jan. 30, 2021. https://www.youtube.com/watch? $\mathrm{v}=4$ YGF9IMHvUc.

Case, Emalani. "I ka Piko, To the Summit: Resistance from the Mountain to the Sea." The Journal of Pacific History Vol. 54, No. 2 (2019): 166-181. Accessed May 31, 2021. https://doi.org/ $10.1080 / 00223344.2019 .1577132$.

Cooper, Lauren. "Native American Activism: 1960s to Present." Zinn Project. N. d. Accessed May 20, 2021. https://www.zinnedproject.org/materials/native-american-activism-1960s-to-present/.

Correia, Cletus. "Wahi Pana O Hawai'i: Connection and (Re)Collection." Hohonu Vol. 13, (2015). Accessed May 20, 2021. https://hilo.hawaii.edu/campuscenter/hohonu/volumes/documents/ WahiPanaOHawaii-ConnectionandReCollectionCletusCorreia.pdf.

Datta, Ranjan. "A relational theoretical framework and meanings of land, nature, and sustainability for research with Indigenous communities." Local Environment Vol. 20, no. 1 (2015): 102-113. Accessed June 3, 2021. http://dx.doi.org/10.1080/13549839.2013.818957.

Dekneef, Matthew. “Reviving Kanaloa.” Flux Hawai i, n.d. Accessed Jan. 30, 2021. https:// fluxhawaii.com/reviving-kanaloa/.

Dudley Kioni, Leon Siu, and Poka Laenui. "Unsettling truths about the 1959 Statehood vote in Hawai' i." My Turn. West Hawai' i Today, August 16, 2019. Accessed June 7, 2021. https:// www.westhawaiitoday.com/2019/08/16/opinion/my-turn-unsettling-truths-about-the-1959statehood-vote-in-hawaii/.

“Ed Greevy." Long Story Short with Leslie Wilcox. PBS Hawai`i. Video, 26:46. June 8, 2020. Accessed Jan. 13, 2021. https://www.youtube.com/watch?v=JuE0ypUUW-A.

Enomoto, Kekoa Catherine. "The Kaho'olawe Nine 30 Years Later.” The Maui News, April 04, 2006. Accessed Jan. 27, 2021. https://www.moolelo.com/kahoolawe-nine.html.

Eisenstein, Charles. Sacred Economics: Money, Gift, and Society in the Age of Transition. Berkeley, Calif.: Evolver Editions, 2011.

Fanon, Frantz. The Wretched of the Earth. 1961. Transl. Constance Farrington. New York: Grove Press, 1963.

Feder, Toni. "Q\&A: Kealoha Pisciotta, on Mauna Kea and conflicts of astronomy." Physics Today. 23 Oct 2019. Accessed Jan. 13, 2021. https://physicstoday.scitation.org/do/10.1063/PT. 6.4.20191023a/full/.

Fiskio, Janet. Climate Change, Literature, and Environmental Justice: Poetics of Dissent and Repair. Cambridge: Cambridge University Press, 2021.

Fornander, Abraham. Fornander Collection of Hawaiian Antiquities and Folklore. Honolulu: Bishop Museum Press, 1916.

Freitas, Ku'uipo. “Ku'uipo Freitas: A Message to Kanaka - Educate Yourself.” Mo'olelo Aloha 'Āina. Video, 0:54. May 2015. Accessed Jan. 18, 2021. https://vimeo.com/139045815.

Fricker, Alan. "Economies of abundance.” Futures Vol. 31, iss. 3-4 (1999): 271-280. Accessed June 3, 2021. https://doi.org/10.1016/S0016-3287(98)00134-7.

Fujikane, Candace. Mapping Abundance for a Planetary Future: Kanaka Maoli and Critical Settler Cartographies in Hawai'i. Durham: Duke University Press, 2021. Accessed Jan. 31, 2021. https:// books.google.fr/books? $\mathrm{id}=$ ac3rzQEACAAJ\&pg=PT5\&source=gbs_toc_r\&cad=3\#v=onepage\& $q \& \mathrm{f}=$ false. Google Bks. 
Gallien, Claire, and جاليان كلير. "A Decolonial Turn in the Humanities - المنعطف المقوّّض

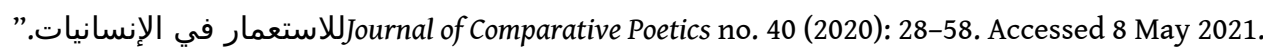
www.jstor.org/stable/26924865.

Goodyear-Ka'ōpua. “Kuleana Lāhui: Collective Responsibility for Hawaiian

Nationhood in Activists' Praxis." In Coulthard, Glen, Jacqueline Lasky, Adam Lewis, and Vanessa Watts (Eds.). Special Issue on Anarch@Indigenism. Affinities: A Journal of Radical Theory, Culture, and Action 5, 1 (2011): 130-163.

Goodyear-Ka‘ōpua, Noelani, Ikaika Hussey, and Erin Kahunawaika'ala Kahunawaika'ala Wright. A Nation Rising: Hawaiian Movements for Life, Land, and Sovereignty. Durham: Duke University Press, 2014.

Gottlieb, Adam. “An Interview with a Mauna Protector.” People's Tribune, July 2, 2019. Accessed Feb. 5, 2021. http://www.peoplestribune.org/latest-news/a-wake-up-call-to-the-rest-of-theworld/.

Haimona-Riki, Mare. "Perpetuating culture amidst adversity." Teao Māori News, Thursday 22 August 2019. Accessed May 19, 2021. https://www.teaomaori.news/perpetuating-culture-amidstadversity.

Hall, Lisa Kahaleole. “All our Relations: Mo`okū’auhau and Mo’olelo.” in Nālani WilsonHokowhitu. The Past Before Us, Mo'okū'auhau as Methodology. Honolulu: University of Hawaii Press, 2019. https://doi.org/10.1515/9780824878177. Kindle version.

Handy, E. S. Craighill, and Mary Kawena Puku i . "The Hawaiian Family System.” The Journal of the Polynesian Society Vol. 59, no. 2 (June, 1950): 170-190.

Hawaiian Dictionaries, Hawaiian Electronic Library, Ulukau, https://wehewehe.org/?1=en.

“Hawaiian Homes Commission Act, 1920," July 9, 1921, c 42, 42 Stat 108, Title 2, §201. Accessed May 27, 2021. https://dhhl.hawaii.gov/wp-content/uploads/2020/02/Hawaiian-HomesCommission-Act-1921-As-Ammended-Searchable.pdf.

“Hawaiian Language College Holds a 'Teach in'." 'Ōiwi TV. Video, 2:56. April 17, 2015. Accessed Jan. 21, 2021. https://oiwi.tv/oiwitv/uhh-teach-in/.

“The Hawaiian Sovereignty Movement: Operating on a False Premise." Nation of Hawai i. 2014. Accessed Feb. 5, 2021. https://hawaiiankingdom.org/blog/the-hawaiian-sovereignty-movementoperating-on-a-false-premise/.

Helm, George. "Kaho`olawe Aloha `Aina - George Helm.” 1977. HawaiianVoice. Video, 26:07. June 11, 2012. Accessed Jan. 13, 2021. https://www.youtube.com/watch?v=kwifpCaanis.

Hermes, Karin Louise. “A new EAducation.” The Hawai i Independent, March 10, 2016. Accessed Jan. 31, 2021. https://thehawaiiindependent.com/story/a-new-eaducation.

Hernández-Ávila, Inés. “The Power of Native Languages and the Performance of Indigenous Autonomy: The Case of Mexico." In Richard Grounds, George E. Tinker and David E. Wilkins (Eds). Native Voices: American Indian Identity and Resistance. Lawrence: University Press of Kansas, 2003: 35-74.

Hobart, Hi'Ilei Julia. "At Home on the Mauna: Ecological Violence and Fantasies of Terra Nullius on Maunakea's Summit." Native American and Indigenous Studies Vol. 6, no. 2 (2019):30-50. Accessed May 31, 2021. www.jstor.org/stable/10.5749/natiindistudj.6.2.0030.

Hitt, Christine. "The Sacred History of Maunakea." Honolulu Magazine, August 5, 2019. Accessed May 25, 2021. https://www.honolulumagazine.com/the-sacred-history-of-maunakea/. 
Hoeschele, Wolfgang. The Economics of Abundance: A Political Economy of Freedom, Equity, and Sustainability. London: Routledge, 2016.

Holt, John Dominis. On Being Hawaiian. 1964. Honolulu: Ku Pa`a Publishing, 1995.

Hota, Jr. “Appreciation of History.” N. d. Accessed June 2, 2021. https://www.herbohtajr.com/ index/history/kahauanulake.html.

Howes, Craig, and Jonathan Kay Kamakawiwo'ole Osorio. The Value of Hawai' i: Knowing the Past, Shaping the Future. Honolulu: University of Hawaii Press, 2010.

Howes, Craig, Noelani Goodyear-Ka'ōpua, Aiko Yamashiro, Jon Kamakawiwo'ole Osorio, and Paige Rasmussen. Value of Hawai'i 3: Hulihia, The Turning. Honolulu: University of Hawai i Press, 2021.

“I OLA KANALOA! A Plan for Kanaloa Kaho'olawe through 2026." Kanaloa 2026 Working Group, 2014. Accessed Feb. 1, 2021. http://www.protectkahoolaweohana.org/uploads/ 1/3/4/4/13443852/i_ola_kanaloa_july_7_2015.pdf.

Jarow, Oshan. “Some Economics of Abundance." Musing Mind, Oct. 24, 2019. Accessed June 3, 2021. https://musingmind.org/essays/economics-of-abundance.

Jewett Chas, and Mark Garavan. "Water is life - an indigenous perspective from a Standing Rock Water Protector," Community Development Journal Vol. 54, iss. 1 (Jan. 2019): 42-58. Accessed June 1, 2021. https://doi.org/10.1093/cdj/bsy062.

Johnson, Hayley. “\#NoDAPL: Social Media, Empowerment, and Civic Participation at Standing Rock," Faculty Publications 28 (2017). Accessed June 2, 2021. https://digitalcommons.lsu.edu/ libraries_pubs/28.

Johnson, Rubellite Kawena. "Puana Ka 'Ike.” Keauhou-Kahalu'u Education Group. Video, 43:22. 2008. Accessed May 13, 2021. https://vimeo.com/22968894.

"Join a Wave of Idle No More Winter Teach-Ins - Idle No More." Idle No More. N.d. Accessed Feb. 5, 2021. https://idlenomore.ca/join-a-wave-of-idle-no-more-winter-teach-ins-idle-no-more/.

Ka iama Manu. “Kū I ka Pono: The Movement Continues.” In Noelani Goodyear-Ka`ōpua, Noelani, Ikaika Hussey, and Erin Kahunawaika'ala Kahunawaika'ala Wright. A Nation Rising: Hawaiian Movements for Life, Land, and Sovereignty. Durham: Duke University Press, 2014.

Kahanamoku, Sara, Rosie 'Anolani Alegado, Aurora Kagawa-Viviani, Katie Leimomi Kamelamela, Brittany Kamai, Lucianne M Walkowicz, Chanda Prescod-Weinstein, Mithi Alexa de los Reyes, and Hilding Neilson. "A Native Hawaiian-led summary of the current impact of constructing the Thirty Meter Telescope on Mauna Kea." Cornell University (2020). Accessed January 12, 2021. https://arxiv.org/abs/2001.00970.

KAHEA: The Hawaiian-Environmental Alliance. Mauka to Makai iss. 1, 2010. Accessed May 14, 2021. https://dlnr.hawaii.gov/mk/files/2016/10/B.01k-Mauka-to-Makai-2010_01.pdf.

Kamakau, Samuel Manaiakalani. Ka Poe Kahiko. 1963. Trans by Mary Kawena Puku`i. Ed. by Dorothy Barrère. Honolulu: Bishop Museum Press. Kindle. 2011.

Kame 'leihiwa, Lilikalā. "Hawai'i-nui-akea Cousins: Ancestral Gods and Bodies of Knowledge are Treasures for the Descendants.” Te Kaharoa Vol. 2 (2009).

Kamelamela, Katie. “The Protect Mauna Kea Movement: Since Before the Overthrow in 1893.” Reterritorialising Social Media: Indigenous People Rise Up. Journal of Global Indigeneity Vol. 1, iss. 2 (2015). Accessed June 2, 2021. https://ro.uow.edu.au/jgi/vol1/iss2/. 
Kanahele, Edith Kanaka`ole. Kü'ula - Kumulipo \& Puke No'eau. Edith Kanaka'ole Foundation, 2003.

Kanahele, George. Kū Kānaka: Standing Tall. Honolulu: University of Hawai i Press and Waiaha Fondation, 1986.

Kapi 'ikauainamoku, Samuel Apolo. "Song of Eternity." Honolulu Advertiser, Aug. 21, 1955. Accessed June 2, 2021. http://www.ulukau.org/elib/cgi-bin/library?e=d-0soe-000Sec--11en-50-20-contactbook--1-010escapewin\&a=d\&d=D0.3.1\&toc $=0$.

Kauanui, J. Kehaulani. Hawaiian Blood: Colonialism and the Politics of Sovereignty and Indigeneity. Durham, NC: Duke University Press, 2008.

Kauanui, J. Kehaulani. "Sacrality, secularity, and contested indigeneity." The Immanent Frame (2017): 3. Accessed May 31, 2021. https://tif.ssrc.org/2017/06/23/sacrality-secularity-andcontested-indigeneity/.

Kauanui, J. Kēhaulani, and Lisa Brooks. "Lisa Brooks on the Recovery of Native Space in the northeast." In J. Kēhaulani Kauanui and Robert Warrior (ed.) Speaking of Indigenous Politics: Conversations with Activists, Scholars, and Tribal Leaders. Minneapolis: University of Minnesota Press, 2018: 21-34. Accessed 9 May 2021. www.jstor.org/stable/10.5749/j.ctv8j71d.7.

Kelly, Erin I. "The Historical Injustice Problem for Political Liberalism." Ethics Vol. 128, no. 1 (October 2017). Accessed Feb. 5, 2021. https://doi.org/10.1086/692974.

Kelly, John. Excerpted from Turning the Tide: Journal of Anti-Racist Activism, Research \& Education vol. 7, \#3-4 (Summer 1994). Nation of Hawai i. Accessed Feb. 3, 2021. http://www.hawaii-nation.org/ turningthetide-7-1.html.

Kikiloi, Kekuewa. "Rebirth of an Archipelago: Sustaining a Hawaiian Cultural Identity for People and Homeland." Hūlili: Multidisciplinary Research on Hawaiian Well-Being vol. 6 (2010).

Kimmerer, Robin Wall. “The Serviceberry: An Economy of Abundance.” Awasqua. Jan. 20, 2021. Accessed June 3, 2021. https://greennetworkproject.org/en/2021/01/20/the-serviceberry-aneconomy-of-abundance/.

“Kōkua Hawai i Oral History Project interview with Darrell Tagalog." In Kubota, Gary. Hawai i Stories of Change: Kokua Hawai i Oral History Project. Honolulu: University of Hawai i Press, 2018. Accessed Jan. 31, 2020: 181-184. https://scholarspace.manoa.hawaii.edu/bitstream/ 10125/59404/1/KHOHP.pdf.

“Kumulipo: Hānau ka Pō.” Kumukahi. Accessed on May 19, 2021. http://www.kumukahi.org/ units/ka_hikina/kumulipo.

LaDuke, Winona. "Protectors, not Protesters: Combating Alternative Facts." Global Institute of Sustainability and Innovation. Video: 4:31. June 12, 2017. Accessed Jan. 20, 2021. https:// www.youtube.com/watch?v=2sAWXT8P-Xs.

LaDuke, Winona. “Mauna Kea Isn't Just About a Telescope, It's About Who Will Decide the Future." Truthout, March 29, 2020. Accessed June 3, 2021. https://truthout.org/articles/maunakea-isnt-just-about-a-telescope-its-about-who-will-decide-the-future/.

Lindo, Cecilia Kapua. "The Spirit of 'Ohana and the Polynesian Voyagers." 1980. Hawaiian Voyaging Tradition. Accessed Feb. 3, 2021. http://archive.hokulea.com/ike/moolelo/ohana.html.

“The Living Island of Kaho`olawe," \#HawaiianPatriots, Kamakakoi. Accessed Jan. 31, 2021. https://www.kamakakoi.com/hawaiianpatriots/george.html. 
"Lonoikamakahiki: Pua Case talks about Lono, Makahiki season, and what that means for us." Kanaeokana. Video, 5:12. Facebook, 2019. Accessed May 19, 2021. https://www.facebook.com/ Kanaeokana/videos/582153979015299/.

Low Sam. “Taking Hold of the Old Story: Sam Ka'ai." 2021. Accessed May 11, 2021. http:// samlow.com/dev/taking-hold-of-the-old-story-sam-kaai/.

Makaawaawa, Brandon. “'These Are Our First Roadways': Internet Access and Self-Determination in Pu'uhonua O Waimanalo." Internet Society, Oct. 14, 2019. Accessed May 21, 2021. https:// www.internetsociety.org/blog/2019/10/these-are-our-first-roadways-internet-access-and-selfdetermination-in-puuhonua-o-waimanalo/.

“The Mālama Honua Worldwide Voyage 2013-2019." Polynesian Voyaging Society. Accessed Jan. 25, 2021. http://www.hokulea.com/worldwide-voyage/.

Mālama Honua charter school. Waimānalo, Hawai i. Accessed Jan. 11, 2021. https:// www.malamahonuapcs.org/.

“Mauna Kea LUC: Gene Tamashiro Testifies (Oct. 25, 2019).” Big Island Video News. Video, 7:10. Posted on 28 Oct. 2019. Accessed May 12, 2021. https://www.youtube.com/watch? $\mathrm{v}=\mathrm{k} 40 \mathrm{wgbK} 9 \mathrm{gxc}$,

McDougall, Brandy Nālani. "Genealogizing Colonial and indigenous Translations and publications of the Kumulipo." In Shu, Yuan, Otto Heim, and Kendall Johnson. Oceanic Archives, Indigenous Epistemologies, and Transpacific American Studies. HK: Hong Kong University Press, Oct 22, 2019: 129-148.

McGregor-Alegado, Davianna. "Hawaiians: Organizing the 1970s." Amerasia Journal 7, 2 (1980): 29-55. Accessed Jan. 20, 2021. https://doi.org/10.17953/amer.7.2.d331761876682740.

Mignolo, Walter D., and Catherine E. Walsh. On Decoloniality: Concepts, Analytics, Praxis. Durham, NC: Duke University Press, 2018.

"The Misuse of the Term Self-determination Regarding Hawai ' 1 ." The Kingdom of Hawai 'i. n.d. Accessed May 25, 2021. https://hawaiiankingdom.org/blog/the-misuse-of-the-term-selfdetermination-regarding-hawaii/.

Murphy Jacqueline Shea. “'Gathering from Within': Indigenous Nationalism and Tanya Lukin Linklater's Women and Water.” Theatre Research International Vol. 35, iss. 2 (July 2010): 165 - 171.

Nicholls, Heidi, and Matt Ito. "Kū Kia'i Mauna: Mauna Kea, Protecting the Sacred, and the Thirty Meter Telescope.” Radio program, 31:10. Accessed on June 8, 2021. https:// religionlab.virginia.edu/projects/ku-kia\%CA\%BBi-mauna-mauna-kea-protecting-the-sacred-andthe-thirty-meter-telescope/.

Niheu, Kalamaoka'āina. “Indigenous Resistance in an Era of Climate Change Crisis." Radical History Review 133 (2019): 117-129. Accessed Feb. 3, 2021. https://doi.org/ 10.1215/01636545-7160101.

Noyes, Martha, dir. Pilahi Paki - Keeper of the Secrets of Hawai'i. 1994. Kōkua Films Hawai ì. Video, 10:01. Posted on Mar 18, 2016. https://www.youtube.com/watch?v=4X7vp3PcdI8\&t=5s.

Office of Hawaiian Affairs (OHA). "A Native Hawaiian Focus on the Hawai'i Public School System, SY2015." Office of Hawaiian Affairs Research Division, April 2017. Accessed Jan. 14, 2021. https:// 19of32x2yl33s8o4xza0gf14-wpengine.netdna-ssl.com/wp-content/uploads/A-Native-HawaiianFocus-on-the-Hawaii-Public-School-System.pdf.

OHA. “Maunakea.” 2021. Accessed June 8, 2021. https://www.oha.org/maunakea/. 
Osorio, Jonathan Kamakawiwo`ole. Dismembering Lāhui: A History of the Hawaiian Nation to 1887. Honolulu: University of Hawai`i Press, 2002.

Paoakalani Declaration, OHA (2003). Accessed May 31, 2021. https://www.oha.org/news/ statement-on-the-aloha-poke-controversy/paoakalani-declaration/.

Peralto, Leon No`eau. "Portrait of Wākea.” In Goodyear-Ka`ōpua, Noelani, Ikaika Hussey; and Erin Kahunawaika'ala Kahunawaika'ala Wright. A Nation Rising: Hawaiian Movements for Life, Land, and Sovereignty. Durham: Duke University Press, 2014: 232-243.

Peralto, Leon No'eau. Kokolo Mai ka Mole Uaua o 'Ī: The Resilience \& Resurgence of Aloha 'Āina in Hāmākua Hikina, Hawai' i. Dissertation in political science. May 10, 2018. Accessed June 3, 2021. https://scholarspace.manoa.hawaii.edu/handle/10125/62705.

Perkins, Misty. "Protectors not Protesters: Indigenous Voice Lost in Translation by Colonialism." Indian Country Today, 21 Oct. 2016. Accessed Jan. 15, 2021. https://indiancountrytoday.com/ archive/protectors-not-protesters-Indigenous-voice-lost-in-translation-by-colonialismM4mPeWQVcUiLK2nIEGO1KA.

Poepoe, Mahilani. “Conversations with La`au Lapa'au Traditional Hawaiian Healer Mahilani Poepoe.” Interview. Worldwide Indigenous Science Network. Video, 14:40, 2016. Accessed May 13, 2021. https://vimeo.com/61475410.

Prejean, Gayle Kawaipuna. ‘Āina Momona, Oct. 29, 2020. Accessed May 10, 2021. https:// www.kaainamomona.org/post/gayle-kawaipuna-prejean.

Prejean, Kawaipuna. “Kawaipuna at Hale o Papa 1992.” Alchetron. Video, 9:05. Uploaded on Jan 27, 2020. Accessed Jan. 16, 2021. https://alchetron.com/Kawaipuna-Prejean.

Privott, Meredith. "An Ethos of Responsibility and Indigenous Women Water Protectors in the \#NoDAPL Movement.” American Indian Quarterly Vol. 43 iss. 1 (Winter 2019):74-100.

Protect Kaho`olawe `Ohana. 2020. Accessed Feb. 3, 2021. http:// www.protectkahoolaweohana.org/.

Pu`uhonua Hawaiian Cultural Village \& Traditional Lo`i Kalo Agricultural Restoration Project. Nation of Hawai i. Accessed May 24, 2021. https://www.hawaii-nation.org/puuhonua.html.

Pu`uhonua o Pu`uhuluhulu University, https://www.puuhuluhulu.com/learn/university.

Puku`i, Mary Kawena, and E.W. Haertig, M.D., Catherine A. Lee. Nānā I Ke Kumu. Vol. II. Honolulu: Hui Hānai, 1972.

Queen Lili`uokalani. The Kumulipo: An Hawaiian Creation Myth (1897). 2d printing. Honolulu: Pueo Press, 1997.

Ramones, Ikaika. "Mauna Kea as Neither Emergency Nor Event." abolition journal, Feb. 19, 2020. Accessed Feb. 3, 2021. https://abolitionjournal.org/mauna-kea-as-neither-emergency-norevent/.

Richardson, Mahealani. "Scientist disputes claims TMT construction spills could contaminate aquifer.” Hawai i News Now, August 13, 2019. Accessed May 14, 2021. https:// www.hawaiinewsnow.com/2019/08/14/uh-hydrologist-disputes-claims-tmt-construction-spillscould-contaminate-aquifer/.

Ritte, Walter. "A Conversation with Walter Ritte 1 of 3." Video, 20:07. Aug. 27, 2012. Accessed June 3, 2021. https://www.youtube.com/watch?v=70bl025C9SU\&t=549s. 
Ritte, Walter. "IUCN: Protecting A Way Of Life On The Last Hawaiian Island." Civil Beat (Sept. 2, 2016). accessed June 1, 2021. https://www.civilbeat.org/2016/09/iucn-protecting-a-way-of-lifeon-the-last-hawaiian-island/.

Rodrigues, Sparky. "Waianae and Mākua Valley: Environmental Dangers, Destruction and Restoration.” APECEpic, 2018. Accessed Jan. 21, 2021. https://www.malamamakua.org/culturalhistory.

Sai, Keanu, "The U.S. Occupation of the Hawaiian Kingdom." Nea Today, Oct. 1, 2018. Accessed June 8, 2021. https://www.nea.org/advocating-for-change/new-from-nea/us-occupationhawaiian-kingdom

Salā, C. Makanani. Blood Quantum and the Department of Hawaiian Home Lands. Master's Thesis in Hawaiian Studies. Honolulu: University of Hawaìi at Mānoa, December 2014. Accessed June 3, 2021. https://scholarspace.manoa.hawaii.edu/bitstream/10125/101134/Sala_Carly_r.pdf

Shay, Susan. "Challenging political agendas through indigenous Media: Hawai' $i$ and the promotion and protection of cultural heritage." In Ciolfi, Luigina, Areti Damala, Eva Hornecker, Monika Lechner, and Laura Maye. Cultural Heritage Communities: Technologies and Challenges. London: Routledge, 2017. Google bks.

Silva, Noenoe K. “The 1897 Petitions Protesting Annexation.” University of Hawai i at Mānoa Library. 1998. Accessed Feb. 1, 2021. http://libweb.hawaii.edu/digicoll/annexation/petition/petintro.php.

Simpson, Leanne Betasamosake. "Indigenous Resurgent Mobilization.” Apr. 9, 2018. Accessed June 1, 2021. http://blogs.law.columbia.edu/uprising1313/leanne-betasamosake-simpsonindigenous-resurgent-mobilization/.

Simpson, Leanne Betasamosake. As We Have Always Done: Indigenous Freedom through Radical Resistance. Minneapolis: University of Minnesota Press, 2017.

Simpson, Leanne Betasamosake. A Short History of the Blockade: Giant Beavers, Diplomacy, and Regeneration in Nishnaabewin. Edmonton: University of Alberta Press, 2021.

Skyhawk, Sonny. "What Percentage Indian Do You Have to Be in Order to Be a Member of a Tribe or Nation? Percentage Indian? Indian Country Today, Sep 13, 2018. Accessed June 3, 2021. https:// indiancountrytoday.com/archive/what-percentage-indian-do-you-have-to-be-in-order-to-be-amember-of-a-tribe-or-nation.

Speidel, Gisela, and Kristina Inn. “The Ocean Is My Classroom." Kamehameha Journal of Education Vol. 5, (1994). Accessed Jan. 11, 2021. https://www.researchgate.net/publication/ 234724920_The_Ocean_Is_My_Classroom.

Spinner-Halev, Jeff. “From Historical to Enduring Injustice." Political Theory Vol. 35, no. 5 (2007): 574-597. Accessed May 11, 2021. www.jstor.org/stable/20452585.

Steele, Julia. "Episode 3: The meaning of aloha 'āina with Puanani Burgess." Aloha Āina. Hawai'i Public Radio. Feb 5, 2016. Accessed Jan. 25, 2021. https://www.hawaiipublicradio.org/post/ episode-3-meaning-aloha-ina-puanani-burgess.

Steele, Julia. “Episode 4: The meaning of aloha 'āina with Dr. Noa Kekuewa Lincoln.” Aloha `Āina. Hawai i Public Radio, Feb 5, 2016. Accessed Jan. 25, 2021. https://www.hawaiipublicradio.org/post/ episode-4-meaning-aloha-ina-dr-noa-kekuewa-lincoln.

Steele, Julia. "Episode 5: The meaning of aloha 'āina with Professor Davianna Pōmaika'i

McGregor.” Aloha `Āina. Hawai i Public Radio, Feb 5, 2016. Accessed Jan. 25, 2021. https:// 
www.hawaiipublicradio.org/post/episode-5-meaning-aloha-ina-professor-davianna-p-maika-imcgregor.

Steele, Julia. “Episode 44: The birth of Hui Aloha 'Āina with Dr. Jon Osorio.” Aloha `Āina. Hawai $i$ Public Radio, Feb 5, 2016. Accessed Jan. 25, 2021. https://www.hawaiipublicradio.org/post/ episode-44-birth-hui-aloha-ina-dr-jon-osorio\#stream/0.

“33 TMT Protesters Issued Citations, Emergency Proclamation at Maunakea." MauiNow, July 17, 2019. Accessed June 2, 2021. https://mauinow.com/2019/07/17/breaking-tmt-protestersarrested-at-maunakea/.

Thrum, Thomas G. Hawaiian Folk Tales: A Collection of Native Legends. Thomas George Thrum ed., 1907.

Trask, Haunani-Kay. Protect Kaho'olawe 'Ohana Tribute to George Helm and Kimo Mitchell, 'Iolani Palace. Video, 6:18. March 5, 1982. Accessed June 3, 2021. https://www.youtube.com/watch? $\mathrm{v}=\mathrm{UQrgw} 8 \mathrm{knxk} 4$.

Trask, Haunani-Kay. "The Birth of the Modern Hawaiian Movement: Kalama Valley, O'ahu." The Hawaiian Journal of History Vol. 21 (1987).

Trask, Haunani-Kay. “Act of War - The Overthrow of the Hawaiian Nation (TRAILER).” 1993. HawaiianVoice. Video, 1:37. March 13, 2012. Accessed Jan. 31, 2021. https://www.youtube.com/ watch?v=qVlbnz011y8\&ab_channel=HawaiianVoice.

Trask, Haunani-Kay. From a Native Daughter: Colonialism and Sovereignty in Hawai i. 1993. Honolulu: University of Hawai i Press, 1999.

Trask, Mililani. "Historical and Contemporary Hawaiian Self-Determination: A Native Hawaiian Perspective.” 8 Ariz. J. Int'l \& Comp. L. 77 (1991).

Tuggle, Myra Jean F. The Protect Kaho'olawe 'Ohana: Cultural Revitalization in a Contemporary Hawai 'i Movement. Master's Thesis in Pacific Islands Studies. University of Hawai i at Mānoa. 1982. Accessed Jan. 17, 2021. https://scholarspace.manoa.hawaii.edu/bitstream/10125/21133/ Tuggle_1982_r.pdf.

Vance, Kamuela. “George Helm - A Hawaiian Legacy.” Kingdom of Hawai ì. Posted March 7, 2011. Accessed June 23, 2021. https://kingdomofhawaii.wordpress.com/2011/03/07/george-helm-ahawaiian-legacy-by-kamuela-vance/.

Villazor, Rose Cuison. "Blood Quantum Land Laws and the Race Versus Political Identity Dilemma." October 23, 2008. Accessed June 1, 2021. http://dx.doi.org/10.2139/ssrn.1288813.

Walker, Isaiah Helekunihi. Waves of Resistance: Surfing and History in Twentieth-Century Hawai'i. Honolulu: University of Hawai i, 2011.

Wilson-Hokowhitu, Nālani, prod. and dir. Po'ele and Kumulipo. Waikato Museum. Video, 3:51. May 25, 2020. Accessed May 13, 2021. https://www.youtube.com/watch?v=vEWbt7cfEQE.

Witze, Alexandra. "How the fight over a Hawaii mega-telescope could change astronomy." Nature 577 (2020): 457-458. Accessed Feb. 2, 2021.

Yamashiro, Aiko, and Noelani Goodyear-Ka'ōpua (Eds.). The Value of Hawai'i 2: Ancestral Roots, Oceanic Visions. Honolulu: University of Hawai'i Press, 2014.

Zuni, Kateri. “8-4-19 -- Indigenous Resistance: From Standing Rock to Mauna Kea,” KUNM. Audio, 35:52. Aug 5, 2019. Accessed June 3, 2021. https://www.kunm.org/post/8419-indigenousresistance-standing-rock-mauna-kea. 


\section{NOTES}

1. Native Hawaiians refer to themselves as Kānaka Maoli, meaning True Human Beings. Kanaka refers to one person or "the whole class of people," or can also be an adjective. The "countable plural form" takes a kahako on the first 'a': Kānaka (Goodyear-Ka'opua, Hussey, Wright, Introduction note1). I will use Kanaka or Kānaka to refer to the people whose ancestors lived in the islands before colonial invasion. I do not use italics for Hawaiian words since that language originates in and is endemic of, Hawai $i$, which is the topic of this paper. I do not speak Hawaiian.

2. I want to acknowledge here the wealth of information and references in those articles and in other works cited in my paper, to which I owe a great deal of the ideas developed in these pages. Heartfelt thanks to my reviewers for their guidance. Any remaining errors are mine. Hobart, "At Home on the Mauna"; Kauanui, "Sacrality" 3; Brown, "Mauna Kea."; Case, "I ka Piko"; Goodyear-Ka'ōpua, "Protectors" 188; Simpson, "Indigenous Resurgent Mobilization."

3. I will capitalize "Protection" in order to distinguish the notion defined in this paper from the ordinary meaning of "something that keeps a person or thing from being harmed, lost, etc." (Merriam Webster); Kū`ē means "To oppose, resist, protest" (wehewehe.org); Mignolo and Walsh, On Decoloniality; Silva, Aloha Betrayed; Beamer, No Mākou Ka Mana; Osorio, Dismembering Lāhui 84-113.

4. Merriam-Webster; at the Native Hawaiian Intellectual Property Rights Conference in October 2003, a great number of cultural experts gathered to discuss the growing commercialization of Kanaka lands and cultural expression. The Paoakalani Declaration was issued reaffirm Kanaka self-determination; Peralto, "Portrait of Wākea" 399; Jewett and Garavan, "Water is life."

5. Aikau and Vicuña Gonzalez, Detours; Goodyear-Ka'ōpua, Hussey, Wright, A Nation Rising; Simpson, As We Have Always Done; Alfred, "Red Power"; Gallien and جاليان كلير, "Decolonial turn."

6. Perkins, "Protectors"; Murphy, "Indigenous Nationalism," is quoted in Fiskio, Climate Change, 127.

7. I call "Protectors" those who have used activism and public strategies to combat attacks on Kanaka history and interests, while using Kanaka epistemologies and mindset to propose alternatives. I have capitalized the word in order to stress on the particular notion of Protection I describe here.

8. Kauanui and Brooks, "Native Space."

9. Peralto, "Portrait of Wākea"; Nicholls \& Ito, "Kū Kia'i Mauna."

10. "ka lani nui" refers to the great heaven or expanse of the sky.

11. Lili uokalani. The Kumulipo Introduction; Beckwith, The Kumulipo 11; Kame`eleihiwa, Native Land 25; Puku'i, Haertig, Lee, Nānā I Ke Kumu. Vol. II, 5; Silva, Aloha Betrayed 87-122.

12. Kanahele, Kü'ula; Kumukahi, "Kumulipo."

13. Wilson-Hokowhitu, Po'ele and Kumulipo; Kanahele, Foreword, in Lili uokalani, Kumulipo, n.p.; "Conversations with Poepoe."

14. Anthropologist Kikiloy reminds us along with most cultural experts that variations in creation accounts, which abound, "only add and build upon the established core 
tradition," (Kikiloy, "Rebirth" 80); $19^{\text {th }}$ century historian Samuel Kamakau, on the contrary, insists on the "contradictory" accounts, Kamakau, Ka Poe Kahiko, Kindle loc. 4128; Kame leihiwa, "Hawai'i-nui-akea Cousins" 47.

15. Fornander, Collection 12; read Ka'opulupulu's story in Thrum, Hawaiian Folk Tales, Ch. XX, 203-214; Peralto discusses the chant and its revelation of Maunakea as the link with the heavens, "Portrait" 236.

16. Kapi 'ikauainamoku, "Song of Eternity; Ibid. 3; Ibid. 1; Ibid. 2; Kikiloy, "Rebirth" 83.

17. Kikiloi, "Rebirth" 76.

18. McDougall, "Genealogizing" 143 note 3; Kauanui, Hawaiian Blood; Salā, Blood Quantum; Sai, "U.S. Occupation; Trask, "Hawaiian Self-Determination" quoted in "Misuse," The Kingdom of Hawai' $i$.

19. Kame`eleihiwa, Native Land, Kindle loc. 5558-5666.

20. McDougall, "Genealogizing” 143, 137; Johnson "Puana Ka 'Ike."

21. Correia, "Wahi Pana"; Ritte landed several times on Kaho'olawe and once eluded searches for an entire month, Ritte, "A Conversation."

22. The spelling of Maunakea, encouraged by UH Hilo School of Hawaiian Language, suggests a name rather than a description, as the mountain's status of kupuna, elder, requires, Hitt, "Sacred History"; Kahanamoku et al., "A Native Hawaiian-led summary."

23. Kauanui, "Sacrality"; "Tamashiro Testifies"; Dudley, Siu, and Laenui, "Unsettling truths."

24. Quoted from Hitt, "Sacred History."

25. Peralto, "Portrait" 233; Datta, "Relational theoretical framework" 103.

26. LaDuke, "Protectors" 1:24; Perkins, "Protectors"; This article is also cited in Privott, "Ethos of Responsibility" 76.

27. Handy and Puku 'i, "The Hawaiian Family System" 175.

28. Kumulipo, Third Era; Peralto, "Portrait" 236; KAHEA, Mauka to Makai;14th Annual Mauka to Makai Virtual Environmental Expo., accessed May 14, 2021, https:// maukatomakaiexpo.com/about; OHA, "Maunakea"; Richardson, "Scientist disputes claim"; Puku 'i and Handy 176.

29. Hermes, "A new EAducation"; Rodrigues, "Waianae and Mākua Valley."

30. Noyes, Pilahi Paki; Kanahele, Kū Kanaka 469, 470-473, 187; Burgess, "reads from The Mouse is Dreaming"; Steele, "Episode 4"; Steele, "Episode 3."

31. Steele, "Episode 5"; Peralto, "Portrait" n18, 242.

32. Yamashiro and Goodyear-Ka'ōpua, Value 2, 211; see also Silva, "1897 Petitions"; Steele, "Episode 44"; Nation of Hawai'i, "Hawaiian Sovereignty Movement."

33. Holt, On Being Hawaiian; Cooper, "Native American Activism."

34. Prejean, “Āina Momona; Prejean, "Kawaipuna”; OHA, "Focus."

35. "Ed Greevy," Long Story Short 16:55.

36. Vance, "Legacy"; Speidel and Inn, "The Ocean" 12; Mālama Honua; Zuni, "Indigenous Resistance."

37. Freitas, "A Message"; "Living Island"; Kanaloa is another name for Kaho'olawe, Dekneef, "Reviving Kanaloa”; "I OLA KANALOA!" 8. 
38. "Join a Wave"; Howes et al., Value 3, 265-267; Pu' uhonua o Pu'uhuluhulu University ; Haimona-Riki, "Perpetuating culture."

39. Freitas, "Hawaiian Language" 2:20; Kanahele, Kū Kānaka 184; Trask, Tribute 3:31.

40. Kīpuka: "a change or variation of form... and especially a clear place or oasis within a lava bed where there may be vegetation" (Hawaiian dictionary, wehewehe.org); Kipuka are places left intact by lava after an irruption and in which fauna and flora are preserved for new growth elsewhere, like a reserve; Fiskio, Climate Change 127; Baker, Ho 'oulu 'äina ii; Low, “Sam Ka’ai”; Peralto, Kokolo Mai vi.

41. Beamer, "Tūtū" 13-15.

42. Vance, "Legacy"; Helm, "Kaho’olawe” 22:40; Goodyear-Ka'ōpua, "Protectors" 191, 193; McGregor-Alegado, "Hawaiians"; Beamer, No Mākou Ka Mana.

43. Goodyear-Ka`ōpua, "Kuleana” 147; LaDuke, "Mauna Kea”; Goodyear-Ka’ōpua, Ibid.

44. Alfred and Corntassel, "Being Indigenous" 605. The phrase "zones of refuges" comes from Hernández-Ávila, "The Power of Native Languages" 38; Goodyear-Ka`ōpua, "Kuleana" 154.

45. Trask, "Birth" 126; Hawaiian Homes Commission Act, 1920; Ho`okupu a ka Lāhui Hawai i: the Master Plan 1995, in Trask, From a Native Daughter 211-236. In the 2000s, an attempt to create a government to government relationship on the model of Native American tribal structures seen by some nationalists as the only way to get some land back and start a self-determination process met with the forceful opposition of others in the Nationalist movement, Kauanui, J Kēhaulani, "Precarious Positions: Native Hawaiians and US Federal Recognition," The Contemporary Pacific 17, no. 1 (2005): 1-27, accessed June 8, 2021, http://www.jstor.org/stable/23721929.

46. This reference ironically alludes to the accusation that the US is a force of occupation in Hawai i, Pu'uhonua Hawaiian Cultural Village"; Makaawaawa, "First Roadways"'; Trask, "Act of War."

47. Fujikane, Mapping Abundance 3; Jarow, "Abundance"; Fricker, "abundance" 271; Hoeschele, Abundance; Kimmerer, "The Serviceberry"; Eisenstein, Sacred Economics; Howes and Osorio, Value; Yamashiro and Goodyear-Ka'ōpua, Value 2; Goodyear-Ka'ōpua et al., Value 3 .

48. The first telescope was built in 1968, Witze "How the fight"; LaDuke. "Mauna Kea"; see the fascinating volume of Simpson, Blockade; Spinner-Halev, "Enduring Injustice"; Kelly, "Historical Injustice."

49. Feder, "Kealoha Pisciotta"; "Mālama Honua."

50. Goodyear-Ka'ōpua, "Kuleana” 153.

51. Fujikane, Mapping Abundance 3, Ramones, "Mauna Kea."

52. Fanon, Wretched 52, Simpson, As We Have Always Done 192.

53. Gottlieb, "Interview"; Niheu, "Indigenous Resistance" 128; "Aloha Rising" 8:25, 13:50-14:14, 16:05, Helm, "Kaho`olawe” 4:47.

54. Ramones, "Mauna Kea." 


\section{ABSTRACTS}

This article means to explicate the notion of Protection claimed explicitly by the Kia $i$, the Guardians or Protectors, of the Mauna Kea summit against the infringement of the TMT project. We must understand how their historical relationship to the land connects Kanaka Protectors to their kuleana, their sphere of responsibility and continual maintenance of its health and bounty. Relationality and a worldview based on a continuum of connections between the universe at large, the land, non-humans and humans is the main framework that allows us to understand not only the actions, but the vocabulary and the mindset in which Hawaiian Protection movements articulate their spiritual and political positions as well as their visions of the future.

\section{INDEX}

Keywords: Hawai' i, Protection, futurities, Indigenous concepts, Maunakea, Kaho`olawe, Noelani Goodyear-Ka`ōpua, George Helm, Pua Case, Ku'uipo Freitas

\section{AUTHOR}

\section{JEAN-MARC SERME}

Jean-Marc Serme is associate professor in Indigenous and US Studies at the University of Western Brittany, France. In recent years, he has focused on the impact of pollution on Native lands, Native public voices, and more recently, he has embarked on a study of the futurity of Native Hawaiian sovereignty in the islands through the exploration of the Hawaiian language immersion and revitalization movement. 